Filol. Linguíst. Port., São Paulo, v. 17, n. 2, p. 309-331, jul./dez. 2015

http://dx.doi.org/10.11606/issn.2176-9419.v17i2p309-331

\title{
Contribuiçôes de José Pedro Machado para o conhecimento da história da antroponímia do português do Brasil
}

\section{Contributions of Fosé Pedro Machado to the knowledge of the history of Brazilian Portuguese anthroponomy}

\author{
A. Ariadne Domingues Almeida* \\ Universidade Federal da Bahia, Salvador, Bahia, Brasil
}

\begin{abstract}
Resumo: Examina-se a antroponímia, usada no Brasil, oriunda do latim e do grego, documentada no Dicionário onomástico etimológico da língua portuguesa (Machado, 2003). Para desenvolver o estudo, seguiram-se os pressupostos teóricos e metodológicos da metalexicografia e da onomástica, de modo a basear-se em autores como Gonçalves (1988). Após a análise do corpus, constituído por verbetes do referido dicionário, concluiu-se que pouco se sabe sobre a antroponímia de fundo latino e grego e que há dúvidas a respeito da etimologia, bem como das motivaçóes para a adoção de item antroponímico no léxico do português do Brasil. Por outro lado, atestou-se que a inegável herança da antiguidade não se restringe apenas ao léxico comum, mas amplia-se para o onomástico.
\end{abstract}

Palavras-chave: Onomástica. Antroponímia. Metalexicografia. Português do Brasil.

Abstract: We examine anthroponomy, used in Brazil, derived from Latin and Greek, documented in an etymologic onomastic dictionary of the

* Professora do Departamento de Letras Vernáculas e do Programa de Pós-Graduação em Língua e Cultura do Instituto de Letras da Universidade Federal da Bahia (UFBA); pesquisadora do Programa para a História da Língua Portuguesa (PROHPOR); e-mail: ariadnealmeida@uol.com.brou ada_domingues@hotmail.com. 
Portuguese language (Machado, 2003). To develop the study, we followed the theoretical and methodological assumptions of metalexicography and onomastics, based in authors such as Gonçalves (1988). After corpus analysis, comprising entries from the dictionary, we concluded that there is a lack of knowledge about Latin and Greek anthroponomy and that there are doubts about etymology and the motivations for the adoption of anthroponomy items in Brazilian Portuguese lexicon. On the other hand, we attested that the undeniable heritage from ancient times is not restricted only to the common lexicon but it expands to onomastics.

Keywords: Onomastics. Anthroponomy. Metalexicography. Brazilian Portuguese.

\section{ANTROPONÍMIA BRASILEIRA E O FUNDO GRECO-LATINO: CONSIDERAÇÓES PRÉVIAS}

quadro que será delineado ao longo do texto ora principiado forja uma imagem adiáfana, até certo ponto, porque, primeiramente, erige-se com base em um conhecimento fragmentário, como é, inclusive, todo e qualquer saber reconstruído pelo devir da história, e também porque se edifica a partir do olhar do pesquisador atual, que não deixa de ser inspirado pelo de um pesquisador de outro tempo, no caso, o de José Pedro Machado; cada qual influenciado por ideologias de sua respectiva época e pela múltipla teia ideológica gerada ao longo dos anos que, de uma forma ou de outra, constrói o imaginário científico de cada e de todo tempo. O texto reflete então uma imagem multidimensional, constituída por diferentes leituras de um fenômeno ainda pouco estudado: a antroponímia em língua portuguesa.

Em síntese, tem-se o objetivo de examinar, sob uma perspectiva metalexicográfica, os prenomes de brasileiros de origem latina e grega constantes do Dicionário onomástico etimológico da língua portuguesa (Machado, 2003), em sua terceira edição. Desse modo, serão abordados alguns fatores que corroboraram para que esses prenomes fossem adotados, mantidos e propagados no léxico antroponímico do português do Brasil.

1 Doravante DOELP.

Almeida, ADA. Contribuiçóes de José Pedro Machado para o conhecimento da história... 


\subsection{Para a construção do estudo: alguns aspectos teóricos e metodológicos}

No Ocidente, a lexicografia possui uma tradição consolidada, de modo que, no devir do tempo, foram produzidas diferentes reflexóes teóricas acerca do labor lexicográfico, em especial no âmbito da análise e da apreciação crítica de dicionários. Mas, embora sempre tenha existido, por meio de reflexóes inseridas em prefácios de dicionários, produzidas em resenhas ou em críticas a dicionários, ou presentes em verbetes de enciclopédias que definem o próprio dicionário ou a lexicografia, ou ainda constantes de artigos e monografias (Welker, 2006), a metalexicografia ou lexicografia teórica é relativamente recente no plano das ciências da linguagem.

No Brasil, consoante Welker (2006), os primeiros estudos metalexicográficos datam das últimas décadas do século XX. Em seu jovem percurso, esse campo do saber hominal que promove conhecimento teórico-metodológico acerca de produtos lexicográficos, e que trata das características reguladoras da estrutura e do comportamento linguístico, tem, entre suas principais orientaçóes, a realizaçáo de pesquisas sobre a tipologia de dicionários, a história da lexicografia e de seus produtos, a crítica a tais produtos, a investigação atinente aos usos dos diferentes tipos de dicionários e das necessidades de seus usuários (Sanromán, 2000).

Se a pesquisa atinente à lexicografia, como afirma Xatara (1998), é no Brasil uma área pouco investigada, ainda menos explorada é a metalexicografia voltada à onomástica. Logo, faz-se necessário desenvolver esse tipo de estudo, uma vez que sua realização colaborará para aprimorar o fazer de dicionários onomásticos, que, inclusive, são parcamente produzidos em língua portuguesa, e corroborará para que se conheça a estrutura desse léxico, uma vez que se compreende que o dicionário tem papel fundamental para isso. Diante de tal cenário, o estudo realizado alicerça-se na metalexicografia, com a finalidade de construir saberes a propósito da constituição do léxico antroponímico, para que, em pesquisas outras, se possa chegar a elaborar aportes para o desenvolvimento de uma teoria acerca da antroponímia brasileira, bem como para examinar o papel do DOELP na descrição desse léxico.

Para atingir a meta proposta, ou seja, para proceder ao estudo dos prenomes oriundos do grego e do latim documentados na terceira edição do DOELP e empregados no português brasileiro, constituiu-se um corpus formado por verbetes constantes dessa obra em que se informasse que o prenome definido é usado no Brasil, bem como se indicasse como étimo uma dessas línguas. Para organização do escopo, foi feita a leitura de todos os verbetes da obra que apresentassem as abreviaturas m. e f., desdobradas na Lista de abreviaturas e siglas da obra como antropônimo masculino e antropônimo feminino, respectivamente. 
Depois de ter constituído o corpus, foram armazenados e organizados, em arquivo digital, os verbetes coletados; na sequência, realizou-se sua leitura e definiram-se as questôes norteadoras do estudo, de forma a propor uma discussão sobre fatores que possibilitaram a adoção, a manutenção e a propagação desse léxico antroponímico de fundo clássico no português brasileiro. Estabelecidas as questôes, efetuou-se a análise de 47 prenomes de origem latina e de 34 advindos do grego, perfazendo o total de 81 itens da onomástica antroponímica brasileira.

A seguir, apresentam-se as reflexóes alcançadas com o estudo desenvolvido, esperando contribuir, de alguma forma, para o conhecimento da antroponímia brasileira, assim como para a solidificação dos estudos onomásticos, ainda incipientes no Brasil.

\subsection{Prenomes latinos: o devir da história do léxico}

Machado (2003) faz menção a usos antroponímicos do português brasileiro, em 580 verbetes destinados a prenomes, de seu DOELP. Conforme o mencionado pesquisador, desse conjunto, 47 são de origem latina, a saber: 1) Aderbal, 2) Agnelo, 3) Agícola, 4) Albo, 5) Alcedo, 6) Ancila, 7) Caio, 8) Cão, 9) Catão, 10) Deusdedit, 11) Diva, 12) Emiliana, 13) Eponina, 14) Eropo, 15) Esmaragdo, 16) Fabiano, 17) Flaminio, 18) Genésio, 19) Getúlio, 20) Glicério, 21) Gloriana, 22) Graciliano, 23) Jafeth, 24) Joana, 25) Magno, 26) Mansueto, 27) Márcio, 28) Mardoqueu, 29) Melibeu, 30) Naasson, 31) Naide, 32) Nobilina, 33) Numa, 34) Paulo, 35) Pérsio, 36) Plotino, 37) Sálvio, 38) Sertório, 39) Sinfrónio, 40) Sisínio, 41) Tácito, 42) Tarquinio, 43) Trajano, 44) Vinício, 45) Virginia, 46) Vitor e 47) Zinia.

O conjunto léxico exposto é formado tanto por itens antroponímicos de uso reconhecidamente comum no português do Brasil, a exemplo de Caio, $\mathrm{Fa}$ biano, Márcio, Paulo e Vitor, quanto por outros aparentemente incomuns, como Catão, Eponina, Pérsio, Plotino e Tácito, e, ainda que alguns sejam, de fato, mais frequentes do que outros, uma consulta a Telelistas.net ${ }^{2}$ revela que a maior parte desses antropônimos - 43 ao todo - é efetivamente empregada no Brasil, de tal

2 Acredita-se que a TeleListas.net pode ser utilizada para ratificar o uso de prenomes no português do Brasil, porque faz mais de uma década que o grupo participa do mercado brasileiro de listas telefônicas impressas e na internet, de modo a cobrir uma rede de mais de 30 milhóes de telefones e atingindo mais de 100 milhóes de pessoas de diferentes grupos sociais do país. [Citado em 20/05/2011]. Disponível em: http://www.telelistas.net/ templates/aempresa.aspx?sec $=0$.

Almeida, ADA. Contribuiçóes de José Pedro Machado para o conhecimento da história... 
sorte que, na posição de prenome, apenas não foram identificados quatro itens do conjunto, quais sejam: Agrícola, Cão, Eropo e Malibeủ .

Ao se considerar o atual conhecimento da formação do léxico antroponímico da língua portuguesa, pode-se afirmar que ainda não é possível informar seguramente se os itens onomásticos ora estudados mantiveram-se do latim ao português, como parece ter sido o caso de Joana, mencionado por Gonçalves (1988) como um nome próprio já utilizado na Idade Média, e como também revela o próprio Machado (2003, p. 828), ao citar como abonação de seu uso um fragmento da cantiga de Burgalês, datada de época próxima aos primórdios da escrita portuguesa:

Joana, $f$., Freqüente, por vezes ainda escrito Johanna (Tel., s.v. Lima, Pires, etc.). Do lat. bíblico Joanna, fem. de Jô(h) annes (ver João, de que é fem. em port.); em S. Luccas, VIII, 3; XXIV, 10; o seu uso foi reforçado pelo facto de também poder funcionar como fem. de Joane (ver João ${ }^{I}$ ). Séc. XIII: "Iahana, dix eu, Sancha e Maria...", Pêro Garcia Burgalês, no C. B. N., no [96]; ver também os nos [197], [198], [1655]. Por vezes aparece em compostos, como Joana Princesa de Portugal, no Maranhão (Brasil), por ter nascido a 12-VI, dia da festa litúrgica da Santa de Aveiro, e Joana d'Arc, "moça solteira", em 1608 (Anais-Faro, IX, p. 131, também usado no Brasil; reapareceu no D.N.de 6-V-1981, p. 17 (natural de Loulé).

Assim, o antropônimo Joana, segundo Machado (2003), aparece documentado tanto nos princípios da língua portuguesa quanto no período seiscentista, especificamente em 1608, e, depois, nos anos oitenta dos novecentos, em 1981.

Por outro lado, antropônimos advindos do latim podem ter sido incorporados como latinismos, a partir do Humanismo e de outras épocas posteriores ${ }^{4}$, o que pode ter acontecido, por exemplo, com Zínia, item onomástico criado a partir do chamado latim científico, como demonstra Machado (2003, p. 1501): "f., Vários casos em Portugal e no Brasil. Do nome da flor de planta (Zinnia em

3 Nobilina não foi citado entre os cinco itens desusados, porque aparece com poucos registros na Telelistas.net na posição de segundo nome.

4 Inclusive, vale destacar que a percepçáo desses antropônimos, no Renascimento, pode ter ocasionado mudanças semânticas, como ocorreu com Diva, segundo preleciona Machado (2003): "Diva, f., (Tel. s.v. Ourique). Do lat. diva, "deusa" (ver Déia). Com o Renascimento começou o uso de Divo como equivalente de Santo, daí Divus Antonius. Santa Maria era Diva Maria.". 
lat. científico) originária das Américas, especialmente do México, assim chamada por causa de J. G. Zinn, que foi director do Jardim Botânico da Universidade de Göttingen”.

Por ser o latim, durante séculos, fonte para a criaçáo do léxico português, constata-se que nem todos os prenomes oriundos dessa língua provêm de um fundo patrimonial, como parece ser o caso de Albo, que, segundo Machado (2003), é "adaptação moderna do lat. albu-, 'branco"'.

Um item léxico antroponímico, inclusive, pode ter diferentes vias de penetração na língua, a exemplo Fabiano. A forma patrimonial seria Fabião, portanto sem o /-n-/ e com a ditongação /âw //, como já foi de certo modo evidenciado no DOELP: " m., [...] Do lat. Fabianu-, der. de fabiu-(Ver Fábio) [...] Fabiano é forma culta, imposta por via eclesiástica ou pelo ingl. Fabian. Há o divergente Fabião” (Machado, 2003, p. 612).

Por terem os antropônimos diferentes entradas na língua, as dataçôes podem ser igualmente variadas; uma possível explicação é o fato de o léxico sofrer influências extralinguísticas atreladas, por exemplo, à moda de um tempo. Perante a presença ou a ausência de um antropônimo em dado período da língua e ao mesmo tempo de sua inclusão ou exclusão ao longo da história dessa mesma língua, pode-se pensar que os itens se encontram estocados na memória coletiva, aguardando novo acesso por parte dos falantes, ou ponderar que podem ser abandonados, obliterados e posteriormente (re)incorporados por influências extralinguísticas, sem qualquer relação com aqueles que outrora foram utilizados por outra geração. Em consequência disso, portanto, ter-se-iam diferentes itens com novas datas.

A datação do léxico antroponímico em língua portuguesa ainda é uma questấo bastante obscura. Em sua obra, Machado (2003), no caso de alguns verbetes, não oferece data alguma para os antropônimos nesses definidos; tal comportamento pode ser observado no verbete Ancila: (" $f$., Do lat. ancilla, dimin. De ancula, 'serva, escrava'. Tenho conhecimento deste nome no Brasil”), Eropo (“m., usado no Brasil. Do lat. Aeropu-, ou f. de Eropa (q.v.)") e Naide ("f., usa-se no Brasil. Do lat. Naide (ver, no pl., Náiades). Cp. Náiades.”) (Machado, 2003, p. 132; p. 575; p. 1057)

Além do silenciamento completo em relação às dataçóes, certas referências à época de utilização dos antropônimos são parcas, uma vez que pouco ou até mesmo nada esclarecem acerca de seus respectivos percursos históricos, a exemplo do que se observa com as informaçóes dadas por Machado (2003, p. 561) a respeito de Emiliana ("f., (Tel., s.v. Carvalho; D. N. de 21-VII-1978, p. 12; no Brasil, a escritora Emiliana do Amaral, nascida em 1885). [...]”) e a propósito de Esmaragdo ("m., Nome de magistrado bras. (Esmaragdo de Freitas; 1887-1946). 
(G.Enc.-Bras., II, p. 875). [...]"). Com o primeiro exemplo, pode-se depreender que o prenome acha-se registrado na década de 1970 e anteriormente na última vintena do período oitocentista, e, com o segundo exemplo, é possível concluir tâo somente que, entre o final do século XIX e a primeira metade do XX, o antropônimo definido era utilizado no Brasil. Entretanto não há como saber, pelos informes constantes do DOELP, se esses antropônimos já eram empregados anteriormente com dataçóes mais antigas.

Em outras situaçôes, porém, visualiza-se melhor o trajeto histórico de um elemento antroponímico, ao longo de sua história, a exemplo das explicaçóes a respeito de Paulo:

m., [...] por via culta. Paulus em 977 (Dipl., p. 76 e 77); de qualquer modo o uso corrente deste antr. entre nós parece moderno; nos séc. XV e XVI, por exemplo, em textos portugueses refere-se sempre a São Paulo e a papas (F. Men., I, p. 13, 14, 174, etc.), L. Cons. (p. 21, 31, 50, etc.), Desc. (II, p. 45, 49, 70, etc.). São freqüentes antr. compostos como Paulo Krüger e Paulo Tacla, usados no Brasil, como Paulo de Tarsos (Machado, 2003, p. 1143).

No caso anteriormente expresso, parte do percurso do antropônimo definido é apresentada, desde o século X, passando pelas centúrias quatrocentista e quinhentista, e, embora procedendo a um corte na linha do tempo, chega-se a informar usos atuais no Brasil.

No verbete destinado a Virgínia é oferecido outro exemplo de explicitação da trajetória histórica do uso de um item onomástico:

f., freqüente, isolado e no conjunto como Maria Virgínia. Do lat. Virgínia, fem. de Virginius, antes Verginius, nome de uma gens romana. Esse nome popularizou-se com a história da jovem plebéia romana (séc. V a. C.) e, mais tarde e entre nós, pelo sucesso da actriz Virgínia (1850-1922); não se esqueça, porém, o romance de Paulo e Virgínia de Bernardin de Saint-Pierre (1737-1814), aparecido em 1786. Como apel. em Tel. O masc. Virgínio, é raro (no Voc.); notar o ainda mais raro Virginius usado no Brasil (G. Enc.-Bras., II, p. 916-917)5.

5 A seguir, apenas uma nota para o conhecimento da história de Virgínia, consoante palavras de Guilherme Bollorini (2011, p. 1). Pelo que assegura o referido autor, o patrício, jurista 
No caso desse verbete, Machado (2003, p. 1842) menciona a propagação desse antropônimo no século $\mathrm{V}$ a. C., depois cita usos dos setecentos, oitocentos e novecentos.

Em seu dicionário, em alguns momentos, Machado (2003) expressa suas hesitaçôes no tocante aos registros de uso do item onomástico definido, como ocorre no verbete Catão, no qual se pode conhecer parte do emprego desse item léxico, além das dúvidas do pesquisador:

Catão [...] Bocage (I. p. 478) referiu-se ao "Censor Catáo", tal como no séc. XVI a EUfr. ('Catm Censorino', p. 12), que também regista 'Marco catam' (p. 62), "Catam Uticense" (p. 263) e só "Marco Catam" (p. 62), "Catam Uticense" (p. 263) e só Catam (p. 125). Antes Gatom no L. Cons., p. 22 e 70. Embora raro, ocorre hoje como antr.; em Portugal, conheço o caso de Catão Simões (1851-1931, na G. Enc., 29o, p. 53); no Brasil do Senhor Catão Maranhão, em S. Luís do Maranhão. Não sei se estão relacionados com este antr. os apel. medievais Catom (Script., p. 365) e Catonis (este em 1008, Dipl., p. 125). (Machado, 2003, p. 375)

Relativamente ao gênero, percebe-se que, no DOELP, a maior parte documentada de prenomes de origem latina usada por brasileiros é masculina, perfazendo um total de 37 prenomes $^{6}$ ou 38 ao se somar o registro masculino constante de um

e decênviro Apio Cláudio "apaixonou-se por uma plebéia, chamada Virgínia, filha de um centuriáo (Virgínio). Como o casamento entre patrícios e plebeus estava proibido pela Lei das XII Tábuas, tramou Apio Claudio induzir um cliente a reclamar Virgínia, em juízo, como sua escrava. A causa foi então submetida a julgamento, sendo que o juiz era o próprio Apio Claudio, conforme havia planejado. Ato contínuo, recusou-se a aplicar um dos dispositivos da Lei das XII Tábuas, que permitia à pessoa reclamada como escrava permanecer em liberdade até a lide ser definitivamente julgada. O pai de Virgínia, percebendo que sua filha cairia sob o poder de Apio Claudio, matou-a com um punhal. Então, estalou a revolução (em 449 a.C.), tanto mais porque os decênviros já manifestavam tendência de querer permanecer no poder, mesmo após o prazo final de entrega de seus mandatos, a que se recusaram ao final daquele ano. [Com] o restabelecimento da ordem, novamente se reúnem os comícios por centúrias, e a Lei das XII Tábuas é finalmente aprovada".

6 Os antropônimos masculinos são: 1) Aderbal, 2) Agnelo, 3) Agícola, 4) Albo, 5) Alcedo, 6) Caio, 7) Cão, 8) Catão, 9) Deusdedit, 10) Eropo, 11) Esmaragdo, 12) Fabiano, 13) Flaminio, 14) Genésio, 15) Getúlio, 16) Glicério, 17) Graciliano, 18) Jafeth, 19) Magno, 20) Mansueto, 21) Márcio, 22) Mardoqueu, 23) Melibeu, 24) Nadsson, 25) Numa, 26) Paulo, 27) Pérsio, 
verbete para um item feminino ${ }^{7}$. Tal número é elevado, se cotejado com a parca identificação de femininos, que totalizam apenas dez prenomes ${ }^{8}$, embora cresçam em mais oito ao se considerarem as indicações de femininos feitas em determinados verbetes para masculinos 9 . O registro, no DOELP, exclusivamente masculino ou feminino obviamente não quer dizer que um ou outro não fosse empregado concomitantemente ao gênero oposto.

No que concerne à motivação, a presença de um item antroponímico no Brasil, oriundo do latim, pode atrelar-se à existência ou à coexistência de certos fatores, como a inspiração religiosa, política, militar e literária.

No tocante à interferência religiosa, especificamente bíblica, verifica-se, com a consulta ao dicionário organizado por Machado (2003), que itens antroponímicos nomeadores de parentes de personagens de relevo do Antigo Testamento foram incorporados ao léxico da língua portuguesa. Em relação ao percurso histórico desses itens, pouco ainda se pode dizer. Gonçalves (1971) chama atenção para o uso de nomes de étimo hebraico em comunidades judaicas da Idade Média, a exemplo de Abraão, Ester, Isaac, Moisés e Salomão. No Brasil de hoje, sabe-se que a complexa teia religiosa, englobando católicos e diferentes grupos de evangélicos, colabora sumariamente para a manutenção e/ou (re)incorporação de itens antroponímicos no léxico onomástico.

28) Plotino, 29) Sálvio, 30) Sertório, 31) Sinfrónio, 32) Sisínio, 33) Tácito, 34) Tarquinio, 35) Trajano, 36) Vinicio e 37) Vitor.

7 O verbete em que se faz menção a um uso masculino é Virginia (“[...] masc. Virgínio, é raro (no Voc.); notar o ainda mais raro Virginius usado no Brasil (G. Enc.-Bras., II, p. 916917)").

8 Os antropônimos femininos são: 1) Ancila, 2) Diva, 3) Emiliana, 4) Eponina, 5) Gloriana, 6) Joana, 7) Naide, 8) Nobilina, 9) Virginia e 10) Zinia.

9 A seguir, apresentam-se os verbetes masculinos, nos quais são feitas referências a usos femininos: 1) Agnelo (“m., [...] Há o f. Agnela (locutora da R.D.P.)”); 2) Genésio (“m., [...] No Brasil ouvi o fem. Genésia”); 3) Graciliano("m., [...] Nasc.-II e Voc. também mencionam o fem. Graciliana”); 4) Márcio(“m., [...] Era raro, em Portugal ao contrário do seu fem. (ver Márcia)”); 5) Sertório (“m., [...] Como alc. de mulher no D. N. de 27-I-1979, p. 12, mas também há o antr. f. Sertória (em Tel., s. v. Jesus)”); 6) Sinfrónio (“m., [...] mas o fem., Sinfrónia, em 1755 (Jornal de Sintra de 17-X-1980, p. 6); este no Voc., em Nasc.-II”); 7) Sisínio (“m., [...] O fem., Sisinia, é usado no Brasil, também escrito por vezes Sizinia”) e 8) Tarquinio (“m., [...] Há o fem. regular Tarquinia (Voc.)”). (Machado, 2003) 
A propósito dos antropônimos registrados na $\mathrm{Bíblia}^{10}$, utilizados por brasileiros, pode-se asseverar, por exemplo, que a documentação de $C a \tilde{a} o^{11}$ e de Jafeth, no DOELP, justifica-se provavelmente pelo episódio do dilúvio. Pelos relatos bíblicos, depois da inundação cataclísmica de toda a superfície terrestre, que durou quarenta dias e quarenta noites, foram os descendentes de Noé os povoadores da terra, uma vez que, consoante o Antigo Testamento, toda a substância feita por Deus teria sido por ele próprio desfeita (Gênese, VI, 10). A memória criada desse castigo divino gerou, possivelmente, no imaginário coletivo, a necessidade de imputar a seres humanos de futuras geraçóes os nomes dos descendentes de Noé que seriam, consequentemente, os ascendentes de todos os futuros humanos. Daí, entre outros, Cão e Jafeth terem sido adotados, em algum momento da história de língua portuguesa:

Cão ${ }^{1}, m$., Filho de Noé. Do lat. Cham, com origem no hebr. hãm, "quente" (Gênesis, X, 6), em alusão às regiôes do sul de clima quente (Withycombe, s.v. Ham). Nasc.-II, s.v., que dá a forma Cão ${ }^{1}$ ocorrente em Gregório de Matos (Obras, VI, 184).

Jafeth, m., (Tel., s.v. Santos, Otil...). Do lat. Japhet(h), este do hebr. Yepheth, de significação incerta (ver Hastings, s.v. Japheth), certamente pelo gr.. Assim se chamava um dos filhos de Noé. [...] No Brasil usa-se Jafé e, segundo Nasc.-II, s.v., já assim teria escrito Gregório de Matos (1633-1696), VI, p. 184. (Machado, 2003, p. 819)

Mardoqueu, tio de Hadassa, Ester, como narrado na Bíblia, livrou o rei Assuero de uma conspiração idealizada por dois de seus camareiros, e, com a sobrinha, ajudou a salvar o povo judeu da perseguição impetrada por Hamá. Como consequência de seus atos rememoráveis, o antropônimo que o nomeava foi usado no devir da história léxica. Afinal, ainda conforme o Antigo Testamento, "o judeu Mardoqueu foi o segundo depois do rei Assuero, e grande entre os judeus, e estimado pela multidão de seus irmãos, procurando o bem do seu povo, e proclamando

10 A edição utilizada neste artigo é: A Bíblia Sagrada contendo o velho e o novo testamento. Tradução de João Ferreira de Almeida. São Paulo (SP): Sociedade Bíblica do Brasil; 1995.

11 Como já pontuado, Cão encontra-se em desuso, pelo menos no Brasil. Como pode se verificar com a leitura do verbete, Machado faz referência à obra de Gregório de Mattos, portanto, a outro período da língua, longínquo, em relação ao momento atual. 
a prosperidade de toda a sua descendência" (Ester, X, 3). Daí, provavelmente, encontrar-se no DOELP:

m., Do lat. Mardochaeu-, nome do Antigo testamento de um tio de Ester (ver Ester, II, 5, 7, 10, 15, 19, 21, 22; III, 2, 5, 6, etc.). Este nome usa-se no Brasil e já o vi escrito (mas perdi a indicação). Mardocheu. $\mathrm{O}$ voc. lat. poderá ter origem hebr.; em Verbo diz-se que é babilônica, der, de Marduc (q.v.). (Machado, 2003, p. 945)

Por sua vez, como expresso no Êxodo, Nadsson foi cunhado de Aarão ("E Arão tomou por mulher Eliseba, filha de Aminadabe, irmã de Naasson"); ele teria colaborado com o mesmo Aarão e com Moisés: ("Da idade de vinte anos para cima, todos os que em Israel podem sair à guerra, a estes contareis segundo os seus exércitos, tu e Arão. 4 Estará convosco, de cada tribo, um homem que seja cabeça da casa de seus pais [...] De Judá, Naasson, filho de Aminadabe") (Números, I, 3, $4,7)$. Depois, ele seria visto como futuro "príncipe dos filhos de Judá" (Números, II, 3). É provável, assim, que a influência bíblica explique a existência do item onomástico Naasson em português:

m., Do lat. Nahason, Nahasson (Êxodo, VI, 23; I Paral., II, 10, 11, etc.; Números, I, 7; II, 3, etc.), devido ao hebr. Nahshon, nome de um cunhado de Aarão. Séc. XV: "Esse Naasom foy cabedell no deserto de toda albergada do tribo de Judá", Script., p. 232. Modernamente, este nome aparece no Brasil: o escritor Naasson Figueiredo (G. Enc.-Bras., II, p. 799 b.). (Machado, 2003, p. 1055)

Ainda no tocante à influência religiosa, alguns itens léxicos nomeadores de homens e de mulheres santos podem ter sido mantidos do latim ao português, bem como difundidos, posteriormente, nessa última língua, devido à pujança adquirida ao longo dos tempos pelo cristianismo no âmbito do Ocidente. Entre os hagiônimos, documentados no DOELP como designativos de brasileiros, acham-se: Agnelo, Caio, Deusdedit, Fabiano, Genésio, Getúlio, Graciliano, Joana, Mansueto, Paulo, Sálvio, Sisínio e Vitor.

Alguns desses itens lexicais ainda são bem usuais no Brasil, como Getúlio. Talvez seu registro ao longo da história se justifique por ter sido esse o elemento nomeador de um oficial romano expulso do exército e martirizado ao se confessar cristão. Deve-se observar que, no caso brasileiro, sua propagação encontra-se 
relacionada, também, ao fato de ter sido esse o prenome de um presidente de destaque na história moderna brasileira, tendo alcançado popularidade, inclusive tendo sido considerado por alguns o pai dos pobres, alcunha que remonta ao livro de Bíblico de Jó (29:16) ("Getúlio', m., Do lat. Gaetuliu, nome de mártir romano do séc. III, festejado a 10-VI. Parece tratar-se de voc. aparentado com Gaetulia (ver Getúlia). Nome de Getúlio Vargas, presidente da República do Brasil.”) (Machado, 2003, p. 713).

Paulo é outro antropônimo empregado atualmente no Brasil; tal utilização, provavelmente, ocorre por ter sido esse o designativo de um apóstolo de importância singular para a difusão do cristianismo:

Paulo, m., Do lat. Paul(l)u-, apel. romano (de paulu-, "pequeño"), usado principalmente na gens Aemilia, vulgarizado pelo prestígio do Apóstolo dos Gentios e mártir São Paulo (m. em Roma em 67; n. em Tarso, capital da Cilícia, cerca de 10), cujo nome judaico era Saul; [...] S. Pedro e S. Paulo foram martirizados no mesmo dia, segundo a tradição; daí festa em conjunto a 29 de Junho. O nome Pedro Paulo é mais freqüente do que Paulo Pedro. (Machado, 2003, p. 1143)

O fato de Paulo também ser chamado Saul, como destaca Machado (2003), incita o desenvolvimento de estudos quer a respeito da problemática da mudança de nome, quer a propósito do uso de dois elementos onomásticos por parte da população judaica, que possuía cidadania romana no mundo antigo.

Uma interferência religiosa mais geral é percebida com a adoção do item onomástico Diva, como revela Machado (2003, p. 511): "Do lat. diva, "deusa" (ver Déia)".

A documentação de itens antroponímicos latinos no português do Brasil pode ser esclarecida, da mesma forma, devido ao prestígio alcançado por homens ligados aos espaços político e militar, a exemplo dos itens onomásticos Glicério, Numa, Sertório e Trajano, que nomeavam expoentes dessas esferas.

Marco Pórcio Catão, como sabido, foi político, militar e renomado escritor romano, que exerceu a atividade de censor, e o peso de seus escritos ainda vigoram ${ }^{12}$.

12 O site Uol, por exemplo, apresenta nove pensamentos atribuídos a Catão, quais sejam: 1) "Sê senhor do argumento, e as palavras virão"; 2) "Aprende algum ofício; pois quando a fortuna vai embora de repente, o ofício fica e nunca deixa a vida da pessoa."; 3) "Os sábios 
Daí talvez a alcunha Catão ter passado a épocas posteriores em posição de prenome e de sobrenome, embora, naquela primeira posição, seja hoje incomum:

Catão, m., Do lat. Catône- (epíteto dos Porcii), der. De catus, voc. sabino sin. de acutus. Acerca de Catão o Censor (234-149 a. C.), Plutarco escreveu na respectiva biografia: "A principio ele não usava apelido de Cato, mas o de Priscus e foi por causa da sua grande sensatez que lhe chamaram Cato, nome que os Romanos dáo aos homens de grande experiência” $(\$ 1)$ (Machado, 2003, p. 375).

Numa Pompilio, segundo rei lendário de Roma, foi sucessor de Rômulo e deve ter tido, em seu tempo, papel decisivo no que concerne à garantia do equilíbrio necessário à recém-criada monarquia romana; também a ele é atribuída à reforma do calendário que aproximava o ano civil do solar. Possivelmente por essas razões seu onomástico ainda se documente no Brasil:

Numa, m., (Antr., p. 79). Do lat. Numa, nome do $2^{\circ}$ rei de Roma, Numa Pompílio. Não está provada a relação entre esse antr. e o gr. nómos, "lei", sugerida pelo facto de o mesmo monarca se ter assinalado como legislador. No Voc. É freqüente aquele conjunto Numa Pompilio (Tel., s.v. Fernanades, Pereira, etc.), mais do que o uso de Numa corrente no Brasil (Machado, 2003, p. 1081).

O registro do item léxico Flaminio provavelmente se deve ao político e cônsul, Caio Flamínio Nepos, que viveu na República Romana do século III a.C., de tal sorte que a presença desse item léxico perpetua parte do conjunto onomástico de um homem importante do período republicano: “m., (Tel., s.v.

aproveitam-se dos tolos mais do que os tolos se aproveitam dos sábios, uma vez que os sábios evitam os erros dos tolos, enquanto estes últimos não imitam a prudência dos sábios.”; 4) "É difícil, ó cidadãos, discutir com o ventre, que não tem orelhas."; 5) "Foge do luxo; ao mesmo tempo lembra-te de evitar / O crime da avareza; ambos prejudicam a reputação."; 6) "Os ladrôes de bens particulares passam a vida na prisão e acorrentados; aqueles de bens públicos, nas riquezas e nas honrarias."; 7) "Quando alguém tem motivos para se queixar de um amigo, convém separar-se dele gradualmente e desatar, de preferência a quebrar, os laços da amizade."; 8) "A maior parte das pessoas tornam-se presumidas e orgulhosas com o sucesso." e 9) "Compra náo o que consideras oportuno, mas o que te falta; o supérfluo é caro, mesmo que custe apenas um soldo.”. [Citado em 17 de maio de 2011]. Disponível em: http://pensador.uol.com.br/autor/Catao/.

Almeida, ADA. Contribuiçóes de José Pedro Machado para o conhecimento da história... 
Abrantes; quando ao Brasil ver G. Enc.-Bras., II, p. 726). Do lat. Flaminiu, antr., do adj. flaminius, "relativo a flâmine". Tenho notícia, no Brasil, do antr. composto Caio Flamínio, certamente homenagem a várias personalidades romanas assim chamadas" (Machado, 2003, 647).

Elementos do antropônimo que nomeava o imperador Marco Úlpio Nerva Trajano ainda podem ser encontrados no Brasil:

Trajano, m., Do lat. Trajanu-, nome do imperador romano (53-117), [...] O prestígio desse soberano causou o uso de seu nome entre nós (Tel., s.v. Almeida; Tel., do Porto, 1974-1975, s.v. Mendes) e no Brasil (G. Enc.-Bras., I, p. 221, e II, p. 175); também aparece como apel. (Tel., D.N. de 7-XII-1980, p. 21, e de 1-I-181, p. 26) (Machado, 2003, p. 1426).

Como se sabe, Trajano foi o primeiro imperador não nascido em Roma - era oriundo da Península Ibérica. O conquistador da Dácia, responsável por levar as fronteiras do Império ao ponto máximo de sua extensão geográfica, obteve prestígio em suas funçóes como imperador, o que pode ter contribuído para a difusão do item léxico Trajano na onomástica portuguesa.

Não só os designadores de imponentes personalidades romanas acham-se hoje documentados no Brasil: também se encontram registrados designativos de homens e de mulheres que tentaram resistir ao poderoso Império. A heroína Eponina, verbi gratia, esteve, na época de Vespasiano, junto ao seu marido Júlio Sabino, na insurreição dos galos contra Roma; pelo que se conta, ela viveu durante nove anos escondida com seu esposo e seus filhos em uma caverna, e, por náo terem conseguido o perdão de Roma, acabaram capturados e mortos. O item onomástico Eponina, além de se relacionar ao da citada heroína, liga-se ao da deusa gaulesa Epona, protetora dos cavalos, a deusa da fertilidade: "Eponina, f., Do lat. $E(p)$ ponina ('a protegida de Épona'), antr. f. de origem gaulesa: era nome de heroína gaulesa do séc. I. Em Tel., s.v. Freitas, Maria ...; no Brasil, Eponina Ruas, autora de Ouro Preto, 1958" (Machado, 2003, p. 570).

A existência de alguns antropônimos deve-se a diferentes motivações; como exemplo pode-se mencionar o caso de Glicério, que, para além de ter sido o item léxico nomeador de um mártir, foi também o de um imperador da Roma Ocidental, no poder por apenas um ano: "Glicério, $m$., Do lat. Glyceriu-, nome de imperador do Ocidente (473-474) e de sacerdote mártir da Nicomedia (m. em 303? ) (Vald.) 
(festa a 21-XII), antr. derivado do gr. glykerós, 'de sabor doce'. Já se usava no Brasil em 1846 (G. Bras., II, p. 975)” (Machado, 2003, p. 719).

Outro exemplo é o da utilização de Caio, que pode ser explicada, de um lado, pela importância no mundo antigo do já antes citado cônsul romano Caio Flaminio, e, de outro, pelo fato de ter sido esse o antropônimo de vários santos:

Caio ${ }^{1}$, m., (Tel., s.v. Oliveira). Do lat. Caius (ao lado de Gaius). A igreja festeja santos com este nome a 4-I, 4-X, 20XI. O nome é raro em Portugal, mas tem uso no Brasil (em 1976, havia pessoa assim chamada na directoria da revista Manchete; ver também o $\mathrm{n}^{\circ}$ desta de 14-II-1976, p. 57, e ainda G. Enc.-Bras., II, p. 541). No Brasil também ouvi o conjunto Caio Flamínio (Machado, 2003, p. 310).

Provavelmente, Márcio registra-se em português por ter sido parte do conjunto onomástico Anco Márcio, que nomeava um lendário rei de Roma, embora outros fatos tenham contribuído para sua perpetuação no português:

Márcio, m., (Manchete de 24-VI-1978, p. 151; como sobrenome em Tel., s.v. Costa, Aurélio...). Era raro, em Portugal ao contrário do seu fem. (ver Márcia). Actualmente é nome popularizado pela telenovela brasileira "O Astro" (1978-1979). Do lat. Marciu-, que era nome de uma família romana, à qual pertencera Anco Márcio, um dos reis de Roma. Tal como se verificou com Márcia, a Igreja festeja uma personalidade com este nome; era bispo da Gália (séc. VI), com festa a 5-VII (Vald. que menciona outro a 24-X, mas, afinal, parece tratar-se do mesmo) (Machado, 2003, p. 944).

Conta, portanto, para sua identificação na onomástica do Brasil o fato de esse antropônimo ter nomeado, além do rei romano, um bispo e, séculos depois, um personagem de uma novela de grande repercussão entre os brasileiros, na década de 70 do século XX.

Ao sair da esfera política e passar à literária, averigua-se que essa última pode inspirar, da mesma forma, a adoção de um elemento léxico antroponímico de origem latina, como acontece com Melibeu: "nome poético arcádico. Do lat. Meliboeu-, nome de um pastor (Virgílio, Bucólicas, I, 6), ligado ao gr. melibóas, "grito ou voz agradável" (ver Antr., p. 439). Tem uso no Brasil; ver Nélson Lustoza Cabral, Paisagens do Nordeste, p. 239" (Machado, 2003, p. 975). Talvez, o vigor da interferência literária também possa ser sentido pelo uso de Gloriana: "Personagem 
da Faerie Queene de Edmundo Spenser (1552?-1599); esta "Gloriosa Rainha do País das Fadas" (I, 3) diz-se representar a rainha Isabel I da Inglaterra. Deriva do lat. Gloria. Usa-se modernamente no Brasil" (Machado, 2003, p. 719-720). E ainda Diva pode representar a força da literatura como elemento divulgador de um item onomástico: " $f$., [...] Este antr. conseguiu certa popularidade sobretudo no Brasil, em resultado da do romance homônimo de José de Alencar (1864). No Voc. Ver. Divo." (Machado, 2003, p. 511).

Os nomes de autores dos textos considerados literários podem ser igualmente recobrados para nomear alguém, a exemplo do registro, na antroponímia brasileira, do item onomástico designativo do poeta satírico da Roma Antiga Pérsio: "Na Escola Politécnica da Universidade de São Paulo: o Prof. Dr. Pérsio de Sousa Santos; D. N. de 29-IX-1980, p. 23; id., de 28-X-1980, p. 17. Do lat. Persiu-, antr. m., nome de célebre poeta satírico romano, da época de Nero. Séc. XVII: Bocage, I, p. 478" (Machado, 2003, 1166).

\subsection{Prenomes gregos: o devir da história do léxico}

No DOELP, localizaram-se 34 prenomes oriundos do grego utilizados no Brasil, a saber: 1) Acrácia, 2) Agenor, 3) Ársaces, 4) Cinira, 5) Cleómenes, 6) Creusa, 7) Demóstenes, 8) Dirceu, 9) Eleazar, 10) Epaminondas, 11) Epicteto, 12) Esdras, 13) Eunápio, 14) Evandro, 15) Galeno, 16) Heliodoro, 17) Homero, 18) Ifigénia, 19) Ismérico, 20) Méton, 21) Mirina, 22) Míron, 23) Mirtes, 24) Neide, 25) Nilo, 26) Pausilipo, 27) Sesóstris, 28) Sinésio, 29) Sosígenes, 30) Taumaturgo, 31) Telésforo, 32) Temistocles, 33) Teo e 34) Zoe.

Todos os itens léxicos antes listados, com exceção de Ismérico e Pausilipo, aparecem registrados na Telelistas.net, de forma a evidenciar que ainda são usados na antroponímia brasileira, embora alguns sejam pouco usuais, atualmente, a exemplo de Acrácia, Epicteto, Mirina, Sosígenes e Telésforo ${ }^{13}$.

No que diz respeito à etimologia de itens antroponímicos de origem grega, faz-se necessário pontuar que, de um lado, Machado (2003, p. 707; p. 424; p. 1365), em determinados casos, informa, para um dado antropônimo, o étimo grego como remoto, fazendo-o advir imediatamente do latim, seu étimo próximo, a exemplo de Esmaragdo ("m., [...] Do lat. smaragdu- (< gr. smáragdos), "esmeralda”.) e de Genésio (“m., [...] Do lat. Genesius, este do gr. genésios, "relativo à família,

13 Deve-se informar, também, que, embora o item Ársaces seja utilizado, seu registro ocorre sem a presença do grafema $<-s>$.

Almeida, ADA. Contribuições de José Pedro Machado para o conhecimento da história... 
protector da família", "relativo ao nascimento"). De outro lado, porém, oferece o étimo o grego, mas por meio do latim, como se verifica com Cleómenes ("m., Do gr. Kleoménes, pelo lat. Cleoménes") e com Sosígenes ("m., Do gr. Sosígénes, pelo lat. Sosigenes)". No dicionário, não há, portanto, um critério uniforme no tocante ao oferecimento do étimo. Destarte, elementos onomásticos classificados como latinos são, em última instância, gregos, ou, por outra leitura, diretamente latinos, porém tomados anteriormente do grego, o que evidencia oscilaçáo no estabelecimento dos critérios para a determinação da natureza etimológica do item definido.

Quanto à atribuição do étimo grego, averigua-se ainda que Machado (2003, p. 43; p. 417) possui dúvidas, pelo que se pode depreender pela leitura do verbete Acrácia (" $f$. [...] Creio tratar-se de representante do gr. akrakia ou akrateia, 'incapacidade de se governar ou de se dominar, intemperança: falta de força, fraqueza.”) ou do verbete Cinira (" $f$., [...] Do gr. Kinyra ou lat. cinyra, "harpa de dez cordas, de som triste"). No primeiro exemplo, a utilização do verbo "crer" denota a hesitação relativa à indicação do étimo, e, no segundo, o emprego da conjunção alternativa "ou" explicita, da mesma maneira, a incerteza do dicionarista.

No que tange à datação, identificam-se antropônimos sem qualquer informação referente à data, a exemplo de Mirtes ("f., com uso no Brasil (Nasc.-II, ad., s.v.). Do gr. Myrtís, "baga ou coroa de mirto", donde também Mirtis (q.v.)") e de Teo (" $m$., no Brasil, geralmente escrito Theo: o investigador contemporâneo Theo Brandão. Do gr. Théos, “deus”, “divindade”, cp. Teia”) (Machado, 2003, 1397).

Em outros casos, há a possibilidade de acompanhar, no DOELP, parte do trajeto histórico de um determinado item antroponímico de origem grega, a exemplo de Creusa: "f., ouvido no Brasil [...] Do gr. Kreíousa (em posição superior", "senhora, rainha”), pelo lat. Creusa, mulher de Jasão. Séc. XVIII, em Bocage, I, p. 401. Terá relação com este antr. f. de 984 Creusa, em Dipl.. p. 89 (ver também p. 100)?” (Machado, 2003, p. 470). Também se pode conhecer um pouco da trajetória do item Demóstenes: "m., Do gr. Demosthénes ("força do povo"), pelo lat. Demosthenes. Em 1534, na Mofina Mendes de G.V. (Copilaçam, fl. 20 vs.). Este nome tem uso actual, no Brasil (Antr., p. 24) como em Portugal (G. Enc.-Bras., II, p. 542; Tel., s.v. Lopes, Meaquita, Sasso, etc. D.N. de 1-IX-1977, p. 10)" (Machado, 2003, p. 498).

Relativamente ao gênero, averigua-se que, dos 34 prenomes de étimo grego, 26 são masculinos $^{14}$, número que se eleva para 27 ao se somar a informação de

14 Os prenomes masculinos são: 1) Agenor, 2) Ársaces, 3) Cleómenes, 4) Demóstenes, 5) Dirceu, 6) Eleazar, 7) Epaminondas, 8) Epicteto, 9) Esdras, 10) Eunápio, 11) Evandro, 12) Galeno, 
uso masculino constante de um verbete feminino ${ }^{15}$. Apenas oito são femininos ${ }^{16}$; todavia, ao se considerarem os informados nos verbetes para masculinos, esse número aumenta em mais três itens ${ }^{17}$, perfazendo onze antropônimos.

Por ser a Grécia berço da civilização ocidental, itens antroponímicos que denominavam suas personalidades históricas, seus seres mitológicos, seus homens e mulheres santificados, foram incorporados ao léxico do português, de tal forma que a análise das informaçóes colhidas nos verbetes da obra de Machado (2003) revela que são variadas as motivaçóes para presença de prenomes oriundos do grego no português.

Demóstenes pode ser um exemplo da incorporação no léxico de um elemento onomástico nomeador de um ator social de relevo no mundo grego: “ $m$., Do gr. Demosthénes ("força do povo"), pelo lat. Demosthenes. Em 1534, na Mofina Mendes de G.V. (Copilaçam, fl. 20 vs.). Este nome tem uso actual, no Brasil (Antr., p. 24) como em Portugal (G. Enc.-Bras., II, p. 542; Tel., s.v. Lopes, Meaquita, Sasso, etc. D.N. de 1-IX-1977, p. 10)" (Machado, 2003, p. 498). Pelo que se sabe, Demóstenes viveu entre 384 a.C. e 322 a.C. e foi um relevante orador e político grego.

Os personagens que inspiram usos antroponímicos podem ser expoentes em várias áreas do mundo grego antigo, como a do exército e da política; daí a adoção de itens léxicos, como Epaminondas, homem ilustre do universo bélico tebano, como demonstra Machado (2003, p. 569): "no Brasil, J. Cox, assim como o poeta contemporâneo Epaminondas Cavalcanti. Do gr. Epameinôndas, pelo lat. Epaminondas, nome de célebre general tebano". Por sua parte, Temistocles, general ateniense que derrotou os persas, alcançando grande prestígio, também teve seu onomástico perpetuado: "Temístocles, m., com uso actual no Brasil. Do gr. Themistokles, antr. m., pelo lat. Themistocles" (Machado, 2003, p. 1396).

13) Heliodoro, 14) Homero, 15) Ismérico, 16) Méton, 17) Míron, 18) Nilo, 19) Pausílipo, 20) Sesóstris, 21) Sinésio, 22) Sosígenes, 23) Taumaturgo,24) Telésforo, 25) Temistocles e 26) Teo.

15 A indicação do uso masculino é feita no verbete Ifgénia: "Há o masc. Ifigénio, em Tel., s.v. Almeida, escrito Efigénio" (Machado, 2003, p. 795).

16 Os prenomes femininos são: 1) Acrácia, 2) Cinira, 3) Creusa, 4) Iffé́nia, 5) Mirina, 6) Mirtes, 7) Neide e 8) Zoe.

17 Femininos são indicados nos seguintes verbetes: 1) Evandro (" $m$., [...] O Voc. também menciona o fem. Evandra”).; 2) Heliodoro, (“m., [...] Há o fem. Heliodora (D.N. de 14-IX1977, p. 9); Bárbara Heliodora era o nome da mulher do poeta bras. Alvarenga Peixoto") e 3) Telésforo (" $m,[\ldots] \mathrm{O}$ Voc. também regista o fem. Telésforai. Está relacionado com este o apel. Telesfera (Tel.).?”) (Machado, 2003).

Almeida, ADA. Contribuiçóes de José Pedro Machado para o conhecimento da história... 
A filosofia grega teve, da mesma forma, baluartes cujos antropônimos que os designavam acabaram utilizados para nomear crianças ocidentais, a exemplo de Epicteto, elemento onomástico designativo de um filósofo estoico, mas que viveu parte de sua vida na condição de escravo, o que explica o significado etimológico do seu nome: "Do gr. Epiktetos ('adquirido posteriormente', 'adquirido de fora', 'estranho', 'não natural'), pelo lat. Epictetu-. No Brasil tem certo uso como antr., por vezes escrito Epiteto (ver G. Enc.-Bras., II, p. 839)” (Machado, 2003, p. 569).

Da medicina, outrossim, foram perpetuados itens léxicos que denominavam importantes personalidades gregas; o antropônimo do médico Galeno, exempli gratia, foi incorporado à antroponímia do português, quer como prenome, quer como sobrenome/apelido: "Galeno, m., Foi nome de célebre médico gr. (séc. II). Do gr. Galenós ('calmo, sereno', falando do mar e em sentido figurado) pelo lat. Galenu-. Como sobrenome, o poeta bras. Juvenal Galeno da Costa e Silva (18361932)" (Machado, 2003, p. 687).

Das áreas exatas, o elemento onomástico nomeador do astrônomo, engenheiro e matemático grego Méton de Atenas acabou também sendo abraçado pela antroponímia da língua portuguesa, o que se deve, provavelmente, a sua influência no mundo antigo; inclusive, como se sabe, o calendário grego baseado no ciclo de Meton foi amplamente utilizado, sendo apenas substituído pelo Juliano. Sobre Méton, todavia, Machado (2003, p. 987) não traz informaçôes: "Méton, m., Do gr. Méton, pelo lat. Meton, antr. $\mathrm{m}$. No Brasil, houve um médico com este nome (1843-1893), segundo a G. Enc.-Bras., II, p. 858”.

Das personalidades que exerceram influência nas artes, é incorporado o antropônimo do escultor grego, criador de umas das mais célebres estátuas atléticas - o Discóbolo de Míron ("o arremessador do disco"). Sobre seu antropônimo, Machado (2003, p. 1000) informa táo somente que seu uso atrela-se à influência da história: "Míron, m., Do gr. Mýron, pelo lat. Myron, antr. m. No Voc. Creio que este nome tem uso actual por influência histórica, sobretudo no Brasil (Manchete de 14-II-1976, p. 61)".

No âmbito da literatura, foi herdado o item onomástico nomeador do poeta Homero, embora Machado (2003) não faça, em seu verbete, referências ao autor da Ilíada e da Odisseia. Sabe-se que a existência real ou não do poeta épico gerou a adoção de seu nome, devido à importância para a literatura ocidental das obras que lhe são atribuídas: "Homero, m., Do gr. Homeros, pelo lat. Homeru-. O problema da origem do voc. gr. tem feito correr alguma tinta, até porque, como nome comum, hómeros pode significar "refém" e "cego". Nada se sabe ao certo. 
[...] No Brasil há quem escreva Omero, provavelmente por influência italiana" (Machado, 2003, p 784).

Além disso, de alguma maneira, Píndaro e a fonte Dirce inspiraram Tomás Antônio Gonzaga a adotar a alcunha Dirceu, propagando o uso desse antropônimo. Nesse caso, parece que a força da literatura se revela em diferentes momentos históricos, de modo a justificar o emprego de Dirceu em distintas épocas:

m., Do gr. Dirkaios (de Dirke, fonte e rio na Boécia), pelo lat. Dircaeu- (relativo a Dirce'; da fonte Dirce; epíteto de Píndaro; id. De Polinices"). O nome tomou modernamente certa popularidade, sobretudo no Brasil, por ter sido epíteto arcádico do "inconfidente" Tomás António Gonzaga (17441810), autor dos poemas de amor Marília de Dirceu (1792). Ver Bocage, I, p. 458. Actualmente (1979). Um jogador de futebol bras. chamado Dirceu Lopes (Machado, 2003, p. 510).

Constata-se, ademais, que a inspiração mitológica grega faz-se sentir na utilização de certos prenomes, a exemplo de

Creusa, f., ouvido no Brasil (não Creúsa, como vem no Voc.; ver Vald., p. 385). Do gr. Kreíousa (em posição superior", "senhora, rainha"), pelo lat. Creusa, mulher de Jasão. Séc. XVIII, em Bocage, I, p. 401. Terá relação com este antr. f. de 984 Creusa, em Dipl.. p. 89 (ver também p. 100)? Não confundir com Crusa (Machado, 2003, 470).

A introdução de Neide no léxico antroponímico é motivada, da mesma forma, pela mitologia grega, como informa o próprio Machado $(2003,1066)$ : "Neide, f., ([...] é muito freqüente no Brasil, com a var. Neida, também no Voc.). Do mit. gr. Neis, -idos, o m.q. Nais, -idos, "náide", pelo lat. nais, neis, -idis.".

Uma das alcunhas do soberano deus dos gregos passou a prenome no léxico antroponímico português brasileiro, pelo que demonstra Machado (2003, p. 1143): "Pausílipo, m., Nome de jornalista bras. (Pausilipo da Fonseca, 1879-1934, ver G. Enc.-Bras., II, p. 835). Do gr. Pausilypos ('que mitiga a tristeza'); era um dos epítetos de Zeus".

A integração de um item oriundo do grego, também, pode ser motivada pela Bíblia, a exemplo do que pode ter ocorrido com Eleazar, consoante Machado (2003, p. 554): "Do gr. Elázar (de voc. hebraico que significa "Deus ajuda"), pelo 
lat. Eleazar, o filho de Aarão; antr. No Voc.; lembro o maestro bras. Eleazar de Carvalho.". É o caso ainda de Esdras:

Esdras, m., Do gr. Esdras, pelo lat. Esdras, nome bíblico, de pontífice dos Judeus, durante o cativeiro de Babilônia. O nome tem origem hebraica, mas obscura, como me parece obscura a possibilidade de o aproximar de Ezra (ver Nasc.-II, s.v. Esdras). Hoje tem uso raro, no Brasil (J. Com.), como em Portugal (Hélder Máximo Franco Esdras Martins, no D.N., de 29-XII-1977, p. 15) (Machado, 2003, p. 582) ${ }^{18}$.

A interferência das tradições religiosas no âmbito da introdução de prenomes advindos do grego pode ser sentida, do mesmo modo, pela presença de Zoe na antroponímia portuguesa:

$f$., [...] Do gr. Zoe, "vida", usado pelos judeus alexandrinos como trad. do nome Eva, tornado antr. f. pelos Bizantinos; assim se chamava uma mártir romana do séc. III (festa a 5-VII). A forma Zoe, como disse, é corrente, em Portugal e no Brasil, mas é considerada inexacta (Voc.), a reproduzir o fr. Zoe; na Grä-Bretanha é Zoe ou Zoe (Withycombe). O Voc. cita a var. Zoa (Machado, 2003, p. 1501).

Trata-se de uma referência à primeira mulher mencionada na Bíblia e também a uma mártir romana, possuindo, portanto, diferentes fatores motivadores que justificam sua documentação atual na antroponímia.

Telésforo é outro prenome atrelado ao universo do cristianismo, e sua inclusão no léxico português brasileiro possivelmente atrela-se à importância de um papa que se tornou mártir:

Telésforo, $m$, usado no Brasil. Do gr. Telesphóros ("que leva até ao fim, que acaba, que cumpre", "que decide", "que dirige bem"); pelo lat. Telesphoru-, nome de mártir, de origem grega, que foi papa entre 125 e 136; festa a 5-I e a 22-II (Vald., p.

18 Segundo Machado (2003), esse prenome é raro no Brasil e em Portugal. No entanto, percebe-se que, no Brasil, esse antropônimo não é tão raro. Talvez essa disparidade de informação se deva à influência das igrejas evangélicas em países da América Latina, ocorrendo, por isso, uma recuperação de nomes bíblicos que anteriormente estavam caindo no ostracismo.

Almeida, ADA. Contribuiçóes de José Pedro Machado para o conhecimento da história... 
299). Como apel. do D. N. de 10-VII-1981, p. 18. O Voc. também regista o fem. Telésforai. Está relacionado com este o apel. Telesfera (Tel.).? (Machado, 2003, p. 1394).

Como já destacado, a incorporação de um item antroponímico de origem grega no léxico do português brasileiro pode ser explicada por diferentes motivos; por exemplo, a justificativa pode ser dada, ao mesmo tempo, tanto pela influência exercida por uma personalidade política/bélica quanto pela interferência do espaço artístico, a exemplo do que acontece com Ársaces: "Do gr. Arsákes, pelo lat. Arsâcês, nome de rei dos Partos. No voc. Daí o antr. m., que ouvi no Brasil, Ársace, provavelmente por influência de uma novela de Montesquieu que foi traduzida para port. (por A.V.C.S.) com o título Arsace e Ismênia (Lisboa, 1827)" (Machado, 2003, p. 172). Ao ler o verbete do DOELP, conclui-se que o prenome, em um primeiro momento, foi aderido do grego ao latim por denominar um monarca de grande prestígio no mundo antigo, e, posteriormente, foi difundido por constar da obra do iluminista Charles Montesquieu.

\section{CONSIDERAÇÓES FINAIS}

após o exame dos verbetes destinados no DOELP a prenomes oriundos do latim e do grego utilizados por brasileiros, averiguou-se pela amostra examinada que o conhecimento a respeito da antroponímia de fundo grego-latino é parco, que dúvidas em relação à etimologia persistem e que o conjunto lexical de antropônimos femininos é, ainda, pouco conhecido. No tocante às motivaçóes, visando a explicar a presença de um item antroponímico no léxico do português brasileiro, não há como afirmar, por exemplo, em qual medida antropônimos registrados na onomástica do Brasil justificam-se por influência da mitologia grega ou por qualquer outra motivação. Ademais, na atualidade, elementos como a sonoridade, a percepção de beleza, a influência midiática influem, consideravelmente, para a escolha de um antropônimo.

Por outra parte, contudo, concluiu-se que, em última instância, a vitalidade do mundo antigo no espaço imaginário ocidental ainda possui força suficiente para ser veículo motivador para a adoção de um item antroponímico. Além disso, constatou-se que várias podem ser as razóes da manutenção ou da (re)incorporação desse tipo de elemento onomástico no português do Brasil; os fatores não são apenas os apontados neste estudo - diversos itens antroponímicos, inclusive, devem sua presença, nesse conjunto lexical, a motivos vários, uma vez que os fenômenos relativos a qualquer esfera do léxico de uma língua são multidimensionais. 


\section{REFERÊNCIAS}

A Bíblia Sagrada contendo o velho e o novo testamento. Tradução de João Ferreira de Almeida. São Paulo (SP): Sociedade Bíblica do Brasil; 1995.

Almeida AAD. O que escrevem sobre os prenomes de brasileiros: leituras de José Pedro Machado. [Citado em 01 jan de 2014]. Disponível em: <http://issuu.com/prohpor/ $\mathrm{docs} / \mathrm{v} \_$rias_navega__es_-_portugu_s_a $>$.

Bollorini G. Apio Claudio e a Lei das XII Tábuas. [Citado 15 mai 2011]. Disponível em: <http://www.ccjf.trf2.gov.br/atrium/atrium2/208_tab.pdf>.

Gonçalves I. Amostra de antroponímia alentejana do século XV. Do Tempo e da História. 1971;4:173-212.

Gonçalves I. Antroponímia das terras Alcobacenses nos fins da Idade Média. Do Tempo e da História. 1972;5:159- 200.

Gonçalves I. Imagens do Mundo Medieval. Lisboa: Livros Horizonte; 1988.

Machado JP. Dicionário onomástico etimológico da língua portuguesa. Lisboa: Horizonte/ Confluência; 1981/2003.

Pensador.info. Catấo. [Citado 17 mai 2011]. Disponível em: <http://pensador.uol.com. $\mathrm{br} /$ autor/catao/>.

Sanromán AI. A unidade lexicográfica: palavras, colocaçóes, frasemas, pragmatemas; 2000. [Citado 22 mar 2015] Disponível em: http://repositorium.sdum.uminho.pt/ bitstream/1822/4573/1/A_Unidade_Lexicografica.pdf.

Telelistas.Net. [Citado 20 mai 2015]. Disponível em: http://www.telelistas.net/.

Welker HA. Breve histórico da metalexicografia no Brasil e dos dicionários gerais brasileiros. Matraga. 2006;19:69-84. [Citado 29 jun 2015]. Disponível em: http://www.pgletras.uerj. $\mathrm{br} / \mathrm{matraga/matraga19/matraga19a04.pdf.}$

Xatara CM. A traduçáo para o português de expressóes idiomáticas em francês [tese]. Araraquara: Universidade Estadual Paulista, Faculdade de Ciências e Letras; 1998.

Recebido em: 16/01/2015

Aceito em: 03/07/2015

Almeida, ADA. Contribuições de José Pedro Machado para o conhecimento da história... 